\title{
Piyano Eğitiminde Öğrenme Stilleri ve 5E Modeline Yönelik Etkinliklerin Başarı ve Kalıcılığa Etkisi
}

DOI: 10.26466/opus.728457

\author{
* \\ Yavuz Selim Kaleli ${ }^{*}$ - Aynur Elhan Nayir** \\ * Dr. Öğr. Üyesi, Necmettin Erbakan Üniversitesi \\ E-Posta: yavuzselimkaleli@gmail.com \\ ORCID: $\underline{0000-0001-7485-3098}$ \\ ** Prof. Dr. Necmettin Erbakan Üniversitesi \\ E-Posta: aynur4272@hotmail.com \\ ORCID: $\underline{0000-0002-1964-3829}$
}

\section{Öz}

Bu araştırmada Piyano eğitiminde $5 E$ modeli ve öğrenme stillerine dayal etkinliklerin öğrencilerin başarı ve kalıcllğ̆a etkisi incelenmişsir. Araştırmada nicel yöntemlerden Kontrol gruplu Öntest-Sontest Modeli kullanılmıştır. Araştırma verilerinin toplanmasında Piyano Dersi Başarı Testi ve Kolb Öğrenme Stilleri Envanteri kullanılmıştır. Araştırma verilerinin analiziyle aşă̆glaki bulgu ve sonuçlara ulaşılmıştır. Yapılandırmacı 5e modeli ve öğrenme stillerine göre öğretim yapılan deney grubu ile geleneksel öğretim metodu uygulanan kontrol grubunun piyano dersi sontest, kalıcılık ve piyano çalma becerisi puanları arasında anlamlı bir fark vardır. Deney grubundaki öğrenciler anlaml düzeyde yüksek piyano dersi başarısı, piyano çalma becerisi ve öğrenme kahıcilğğ elde etmişlerdir. 5 E modeli ve öğrenme stillerine dayal öğretim etkinliklerini bir arada uygulayan öğrenciler sistematik bir yaklaşımla kendi öğrenme süreçlerine göre etkinlikleri aktif olarak yapılandırmışlar, aşamalı bir şekilde görsel, işitsel ve kinestetik aktiviteler gerçekleştirmişler ve kubaşık stratejinin deneysel işleminde kendi öğrenme süreçlerini sorgulamışlardır. Bu bütüncül yaklaşım $5 E$ modeli ve öğrenme stillerine dayalı öğretimin uygulamasının piyano dersi başarısı üzerinde yüksek etki oluşturmasına yol açmıştır. Yapılandırmacı ve öğrenme stillerine dayalı piyano eğitiminde her bir öğrencinin tercih, ilgi, ihtiyaç, öğrenme yaşantıları ve bireysel farklılıkları dikkate alınarak, öğretim yöntemleri, ö̆grenme ortamı, ölçme-değerlendirme teknikleri düzenlenmiştir. Bu anlayış çerçevesinde piyano dersinin düzenlenen öğrenme ortamlarında, öğrenciler aktif bir şekilde öğrenme sürecinde sorumluluk almışlar, kendi öğrenme stillerini uygulayarak dersin kazanımlarını elde etmeye çalışmışlardır. Tüm bunlar piyano dersinde yüksek başarıyı, kalıcılı̆̆ı ve olumlu yönde duyuşsal öğrenme ürünlerini ortaya çıkarmıştır.

Anahtar Kelimeler: Piyano Eğitimi, 5E modeli, Öğrenme stilleri, Piyano eğitiminde yapılandırmacllik 


\title{
Effects Of Learning Styles And 5E Model Activities On Success And Permanently In Piano Education
}

\begin{abstract}
In this study, the effects of $5 E$ model and learning styles-based activities on students' success and permanence in piano education were investigated. Pretest-Posttest Model with Control group, which is one of the quantitative methods, was used in the research. Piano Lesson Achievement Test and Kolb Learning Styles Inventory were used to collect research data. By analyzing the research data, the following findings and conclusions were reached. There is a significant difference between the experimental group, which is taught according to the constructivist 5e model and learning styles, and the control group applied the traditional teaching method, the piano lesson posttest, permanence and piano playing skill scores. Students in the experimental group achieved a significantly higher piano lesson success, piano playing skills and learning permanence.

Students who combine $5 E$ model and learning activities based on learning styles actively structured activities according to their own learning processes with a systematic approach, progressively carried out visual, auditory and kinesthetic activities and questioned their own learning processes in the experimental process of the cuban strategy. This holistic approach has caused the application of teaching based on the $5 E$ model and learning styles to have a high impact on the success of the piano lesson. In the piano education based on constructivist and learning styles, considering the preferences, interests, needs, learning experiences and individual differences of each student, teaching methods, learning environment, assessment-evaluation techniques were organized. Within the framework of this understanding, in the learning environments where the piano lesson is organized, students actively took responsibility in the learning process and tried to gain the lesson by applying their own learning styles. All of these revealed high success, permanence and positive affective learning products in piano lessons.
\end{abstract}

Keywords: Piano education, 5e model, Learning styles, Constructivism in piano education 


\section{Giriş}

Müzik eğitiminin en önemli boyutlarından birisini oluşturan piyano eğitimi, bireyin piyano çalması kadar, diğer müzik unsurlarına da etkili bir katkı sağladığı kanıtlanmış bir gerçektir. Eğitim alan bireyin göstereceği çalışma performansı, hangi seviyede piyano çalabileceği ile doğru orantılıdır. Piyano eğitimcisi de, bireyin hedefe giden yollarını doğru bir şekilde belirlemesine yardimci olmalıdır.

Araştırmanın konusu olan yapılandırmacı 5E modeli ve Kolb'un öğrenme stilleri, yukarıda bahsedilen konunun çözümü için, bireyin piyano eğitiminde bu unsurları kullanarak, konuları kendi kendine yapılandırmasını ve çözüm üretmesini sağlamak üzere seçilmiştir.

5E modeli, yapılandırmacı yaklaşımda oldukça fazla kullanılmaktadır. Bireyin araştırma merakını artıran, becerilerin ve bilgilerin devamlı kullanımını içeren etkinliklerden oluşmaktadır. 5E modeli her bölümde öğrencileri uygulama içinde tutarken, aynı zamanda öğrencilerin kendi tanımlarını oluşturmalarını da imkan tanır. 5E modeli, başka bir kavramın öğrenilmesini veya bilinen olgunun daha derinlemesine anlaşılmasını sağlayan bir süreçtir. 5E modeline yönelik araştırmalarda, öğrencilerin başarılarını artırdığı, kavramsal gelişimlerini artırdığı ve tutumlarını olumlu yönde değiştirdiğine dair bulgular bulunmaktadır (Bayar 2005).

Öğrenmede bireysel farklılıklar üzerine birçok çalışma yapılsa da gerçekleştirilen uygulama genellikle istenilen düzeyde gerçekleştirilememektedir. Uygulamada meydana gelen eksiklikler, eğitimcilerin sürekli bu konu üzerinde araştırma yapmalarına neden olmuştur. Yapılan araştırmalarda, bireysel farklılıklardan bahseden önemli kavramlardan birisi de öğrenme stili olarak kabul edilmektedir (Ekici, 2002:42-47).

Öğrenme stilleri bakımından bilişsel farklılıkların tespiti, başka bir öğrenme hayatının saptayıcısı olan öğreten ve öğrenme yerlerinin yeniden tasarımı için önemli bir belirleme aracıdır. Müzik eğitimi gibi, öğrenmede duyuşsal, görsel ve dokunsal aktiviteleri yoğun bir şekilde gerektiren alanlarda çocukların öğrenme stillerinin dikkate alınmasının önemli katkıları olacağı tartışılmaz bir gerçektir. Öğrencilerin bilişsel duyuşsal ve psikomotor alanlarda bireysel farklılıklarının incelenerek müzik öğretiminde öğrenme ortamlarının ve yaklaşımlarının düzenlenmesi bu dersin kazanımlarının gerçekleşmesine katkı sağlayacaktır. Başarılı ve etkili bir müzik eğitimi oluşturabilmesi 
için öğrencilerin bireysel farklılıklarının saptanması büyük önem taşımaktadır. Bu farklılardan önde geleni ise çocukların öğrenme stilleridir (Aşkar ve Akkoyunlu, 1993; Kolb, 1985).

\section{Problem durumu}

Piyano eğitimi bireyin bilişsel, duyuşsal ve devinişsel öğrenme yaşantıları açısından önemli bir değer taşımaktadır. Piyano eğitimcilerinin uyguladıkları öğretimde, öğrencilerin öğrenme stillerini göre etkinlik yapmaları durumunda, öğrencilerin derslerinde daha aktif rol almaları beklenmektedir. Piyano eğitiminde, kazanımların düşük düzeyde gerçekleşmesi durumunda eğitimcilerin, öğrencilerinin öğrenme stillerini hangi düzeyde dikkate aldıkları sorusunu ele almaları gerekmektedir.

Problem Cümlesi: Piyano eğitimde yapılandırmacı 5E modeli ve öğrenme stillerine dayalı uygulamaların bireyin piyano dersi başarısına ve öğrenilenlerin kalıcılığına etkisi var mıdır?

\section{Amaç}

Bu araştırmanın amacını, piyano eğitimi alan bireylerin, piyano çalarken parçanın armonisi, formu ve teknik özelliğine dikkat etmeden çalması yerine, verilecek olan yapılandırmacı ve öğrenme stillerine dayalı piyano eğitimi sayesinde, parçadaki armonik fonksiyonları bilip, hangi formda olduğunu tespit eden ve teknik zorlukları nasıl aşacağını kendi kendine tespit etmesine yardımcı bir "5E Modeli ve Öğrenme Stillerine Dayalı Piyano Eğitimi" uygulaması hazırlama ve bu uygulamanın bireyin piyano çalma becerisine ve kalıcılığına etkisini ortaya koymaktır.

\section{Önem}

Araştırmada uygulanacak olan "5E Modeli ve Öğrenme Stillerine Dayalı Piyano Eğitimi" çalışması, piyano çalan bireylerin çalışma yöntemlerine yön verecek olmasından, piyano eğitimcilerinin ise; piyano öğretimi esnasında 
kullanacakları bir çalışmayı hazırlayacak olması ve yapılandırmacı 5E modeline ile öğrenme stillerine dayalı bir piyano eğitiminin nasıl uygulanacağına rehberlik etmesi açışından, önemlidir.

\section{Sinirliliklar}

Araştırma, Necmettin Erbakan Üniversitesi Ahmet Keleşoğlu Eğitim Fakültesi Müzik Eğitimi Bölümündeki lisans 3. sınıf öğrencilerinden, deney grubunda 12 öğrenci, kontrol grubunda 12 öğrenci olmak üzere toplam 24 öğrenci ve 10 haftalık uygulama süresi ile sinırlıdır.

\section{Yöntem}

Araştırma nicel veri toplama yöntemlerinden deneme modeli boyutunda yapılandırmacı 5E Modeli ve öğrenme stillerine dayalı piyano eğitim uygulamasının, öğrencilerin başarı, öğrenilenlerin kalıcılığına olan etkileri test edilmiştir. Araştırmanın bu süreci gerçek deneme modeliyle gerçekleştirilmiştir. Karasar'a göre (2005) gerçek deneme modellerinde öntest uygulaması, kontrol grubunun varlığı ve deneklerin seçkisiz yöntemle atanması söz konusudur. Bu araştırmada literatürde ifade edilen bu üç temel kural yerine getirilmiştir. Kontrol gruplu öntest-sontest deneme modeliyle desenlenen gerçek deneme sürecinin nasıl işlediği aşağıdaki tablo 1'da gösterilmiştir.

Tablo 1. Araştırmada Uygulanan Deneme Modeli

\begin{tabular}{llllll}
\hline Gruplar & Ön Testler & Deneme Süreci & Son Testler & İşlem Yok & Kalıcılık Testi \\
\hline Deney Grubu & $\mathrm{T} 1_{1}$ & $\mathrm{X}$ & $\mathrm{T} 2_{1}$ & & $\mathrm{~T} 3_{1}$ \\
\cline { 1 - 4 } Kontrol Grubu & $\mathrm{T} 1_{1}$ & - & $\mathrm{T} 22_{1}$ & 3Y & $\mathrm{T} 3_{1}$ \\
\hline
\end{tabular}

Tablo 1'de gösterilen sembollerin açılımı aşağıda verilmiştir.

T1-Öntest T2- Sontest T3- Kalıcilık Testi

T11- Öntest Piyano Dersi Başarı Puanı

T21- Sontest Piyano Dersi Başarı Puanı

T31- Kalıcılık Testi Puanı (Piyano Dersi Başarı Puanı)

X- Yapılandırmacı 5E + Öğrenme Stillerine Dayalı Piyano Eğitim Uygulaması

\section{Geleneksel Öğretim Uygulaması}

Araştırma öncesinde her iki gruba da deneysel işlemden önce öntest olarak deneklere piyano dersi başarı testi, piyano çalma becerisi gözlem formu ve piyano dersine yönelik tutum ölçekleri uygulanmıştır. Öntestin uygulanma- 
sina müteakip ara vermeden deney ve kontrol gruplarına 10 haftalık deneysel işlem gerçekleştirilmiştir. Aynı test ve ölçekler deney ve kontrol gruplarına sontest olarak uygulanmıştır. Bu aşamada deney grubunda yapılandırmacı öğrenme 5E modeli + Öğrenme Stillerine dayalı öğretim uygulaması, kontrol grubunda ise geleneksel öğretim uygulaması gerçekleştirilmiştir. Sontestin uygulanmasından 3 ay sonra tüm gruplara piyano dersi başarı testi 'kalıcılık testi' olarak uygulanmıştır.

Araştırmanın deneysel kısımda, deneye başlamadan önce kontrol ve deney grupları arasında anlamlı bir fark olmaması açısından içinde piyano eğitimindeki genel teknik ve müzikal ifadeleri içeren bir ön değerlendirme formu hazırlanmıştır. Deney aşamasında deney grubuna Kolb'un Öğrenme Stil Envanteri uygulanıp hangi öğrenme stiline uygun olduğu tespit edildikten sonra yapılandırmacı 5E Modeli + öğrenme stilleri öğretim programına göre 10 haftalık piyano eğitimi uygulaması planlanmış ve gerçekleştirilmiştir.

Bu uygulamada günümüzde ayrı ayrı dersler olarak verilen Armoni, Müzik Biçimleri dersi, ve Piyano dersi öğelerini içeren ve bireyin kazanımlarını yapılandırmasına rehberlik edecek nitelikte etkinlikler yer almıştır. Bireyin piyano parçası içerisindeki bilişsel alan becerisini kullanacağı armoni fonksiyonlarının tespiti, piyano parçası formunun ve müzikal dönem farlılı̆̆ının tespiti, duyuşsal alan becerini kullanacağı yine çalacağı parçanın tonunda solfej çalışmaları (örn: sol el çalınırken, sağ elin solfejinin yapılması veya sağ el çalınırken sol elin solfejinin yapılması v.b.), devinişsel alan becerisini kullanacağı, parçanın teknik zorluğu olan yerlerinin hem tartım hem de seslerinin değiştirilip varyasyonlar halinde türetilip piyano performansını artırıcı çalışmalar yazılarak, bireyin bu ayrı dersleri yapılandırmasına rehberlik edecek unsurlar yer almıştır.

\section{Denekler}

Piyano eğitimde yapılandırmacı 5e modeli ve öğrenme stillerine dayalı uygulamaların bireyin piyano dersi başarısına, piyano çalma becerisine, derse yönelik tutumlara ve öğrenilenlerin kalıcılı̆̆ına etkisinin deneysel yöntemle test edilen bu araştırmanın deneme modeli boyutunda deney ve kontrol grupları belirlenmiştir. Bu amaçla 2016-2017 Öğretim Yılında Necmettin Erbakan Üniversitesi, Ahmet Keleşoğlu Eğitim Fakültesi, Müzik Öğretmenliği 
Anabilim Dalında piyano eğitimi dersini alan 24 öğrenci araştırma kapsamına alınmıştır. Bu öğrenciler seçkisiz yöntemle 12'şer kişilik iki gruba atanmıştır. Daha sonra bu gruplar şans yoluyla deney ve kontrol grupları olarak belirlenmiştir. Bu süreçte öğrencilerin cinsiyet açsından gruplara denk atanmasında dikkat edilmiştir.

Deneme sürecinde haftalık 1 saatten 10 hafta gerçekleştirilen bu araştırma bizzat araştırmacı tarafından yürütüldügü için deney ve kontrol gruplarının belirlenmesinde bazı faktörler etkili olmuştur. Bunlar:

- Deneme uygulamalarının gerçekleştirildiği üniversitenin ilgili müzik eğitimi anabilim dalının alt yapısının güçlü olması,

- Deneme uygulamalarının gerçekleştirildiği üniversitenin ilgili müzik eğitimi anabilim dalının köklü geçmişinin olması ve zengin öğretim elemanı dağılımına sahip olması,

- Deneme uygulamalarınn gerçekleştirildiği ilgili müzik eğitimi anabilim dalında uygulanan öğretim programlarının araştırma değişkenleri ile uyumlu olmasi,

- Araştırmacının bu üniversitede doktora yapması nedeniyle deneysel uygulamaları sağlıklı yürütebilmesine imkan vermesi,

- İlgili anabilim dalı ve fakülte yönetimin araştırma uygulamalarına izin vermesi ve destek olması

- Araştırma süreçleriyle ilgili deneme modelinin gerektirdiği kontrollerin etkili bir gerçekleştirilmesine imkan vermesi

- Daha önce ilgili anabilim dalında uygulamalı ve deneysel araştırmaların gerçekleştirilmiş olması,

- Araştırmanın ekonomik ve zaman boyutları açsından sağladığı olanaklar etkili olmuştur.

$\mathrm{Bu}$ araştırmada deney ve kontrol grupları oluşturulduktan sonra grupların denk olup olmadığı kontrol edilmiştir. Bu aşamada:

1. Deney ve kontrol gruplarının cinsiyetlerine göre dağılımı

2. Deney ve kontrol gruplarının öğrenme stilleri açısından dağılımı,

3. Deney ve kontrol gruplarındaki öğrencilerin piyano dersi öntest puanları,

4. Deney ve kontrol gruplarındaki öğrencilerin piyano çalma becerisi öntest puanları,

5. Deney ve kontrol gruplarındaki öğrencilerin piyano dersine yönelik tutumlarındaki denkliğe dikkat edilmiştir. 
Tablo 2. Deney ve Kontrol Gruplarındaki Öğrencilerin Cinsiyete Göre Dağılımı

\begin{tabular}{llll}
\hline \multirow{2}{*}{ Gruplar } & \multirow{2}{*}{} & \multicolumn{2}{c}{ Cinsiyet } \\
\cline { 3 - 4 } Deney Grubu & \multirow{2}{*}{12} & 7 & Erkek \\
\hline \multirow{2}{*}{ Kontrol Grubu } & \multirow{2}{*}{12} & $58.33 \%$ & $31.77 \%$ \\
\hline \multirow{2}{*}{ Toplam } & \multirow{2}{*}{24} & 7 & 5 \\
& & $58.33 \%$ & $31,77 \%$ \\
\hline
\end{tabular}

Tablo 2 'de Yapılandırmacı 5e modeli+öğrenme stillerine göre öğretim yapılan deney grubu ile geleneksel öğretim metodu uygulanan kontrol grubunun cinsiyetlerine göre dağllımları görülmektedir. Deney grubunda $7 \mathrm{kız}$ $(\% 58,33) 5$ erkek $(\% 31,77)$, geleneksel öğretim uygulaması yapılan kontrol gruplarında ise $7 \mathrm{kız}(\% 58,33) 5$ erkek $(\% 31,77)$ öğrenci bulunmaktadır. Araştırmada deney ve kontrol gruplarında cinsiyet açısından birbirlerine eşit bir dağılımın olduğu görülmektedir.

Tablo 3. Araştırma grubunun öğrenme stillerine göre dağılımı

\begin{tabular}{lllll}
\hline & \multicolumn{2}{l}{ DENEY GRUBU } & \multicolumn{2}{l}{ KONTROL GRUBU } \\
\hline Ö̈̆renme Stilleri & $\mathrm{n}$ & $\%$ & $-\mathrm{n}-$ & $\%$ \\
\hline Yerleştiren & 4 & $\% 33,3$ & 5 & $\% 41,7$ \\
\hline Özümseyen & 2 & $\% 16,7$ & 1 & $\% 08,3$ \\
\hline Dönüştüren & 5 & $\% 41,7$ & 5 & $\% 41,7$ \\
\hline Ayriştran & - & & - & \\
\hline Çoklu Stil & 1 & $\% 08,3$ & 1 & $\% 08,3$ \\
\hline Toplam & 12 & & 12 & 100,0 \\
\hline
\end{tabular}

Araştırma öncesinde deney ve kontrol gruplarındaki öğrencilerin öğrenme stilleri açısından denkliğini tespit etmek için iki gruba da Kolb Öğrenme Stilleri Envanteri uygulanmıştır. Uygulama sonucu deney grubundaki öğrencilerin 4 'ünün $(\% 33,3)$ yerleştiren, 2 'sinin (\%16,7) özümseyen, 5 'inin $(\% 41,7)$ dönüştüren ve 1 'inin $(\%, 08,3)$ çoklu öğrenme stillerine sahip olduğu görülmüştür. Kontrol grubundaki öğrencilerin 5 'inün (\%41,7) yerleştiren, $1^{\prime}$ inin $(\% 08,3)$ özümseyen, 5 'inin $(\% 41,7)$ dönüştüren ve 1'inin $(\%, 08,3)$ çoklu öğrenme stillerine sahip olduğu görülmüştür. Her iki gruptaki öğrenciler de ağırlıklı olarak dönüştüren ve yerleştiren öğrenme stillerine sahiptir. Her iki grupta da ayrıştıran öğrenme stillerine sahip öğrenci bulunmamaktadır. Değiştiren stili tercih eden öğrenciler izlemek ve takip etmek için bir modele- 
örneğe ve beraberinde somut bir uyarana ihtiyaç duymaktadır (Yansıtıci+Somut). Yerleştiren stile sahip öğrenciler ise yaparak yaşayarak öğrenme deneyimine ve somut uyaranlara ihtiyaç duymaktadır (Aktif+Somut)

Araştırma öncesinde deney ve kontrol gruplarının öğrenme stilleri açısından birbirlerine denk olduğu görülmektedir.

Tablo 4. Deney ve Kontrol Gruplarındaki Öğrencilerin Öntest Piyano Eğitimi Puanlarnın Karşılaştırılması

\begin{tabular}{lllllll}
\hline & & $\mathrm{N}$ & Mean Rank & Sum of Ranks & $\mathrm{Z}$ & $\mathrm{P}$ \\
\hline ÖnT Piyano Egitimi & 1,00 & 12 & 9,88 & 118,50 & $-1,8562$ & 0,068 \\
& 2,00 & 12 & 15,13 & 181,50 & & \\
& Total & 24 & & & & \\
\hline
\end{tabular}

Tablo 4'da deney ve kontrol gruplarındaki öğrencilerin öntest piyano eğitimi puanları üzerinde gerçekleştirilen Mann Witneu U testi sonuçları görülmektedir. Analizlere göre iki grubun piyano eğitimi testi puanları arasında $1,85 \mathrm{Z}$ değeri hesaplanmıştır. Bu bulgu 0,05 düzeyinde anlamlı değildir. $\mathrm{Bu}$ sonuca göre araştırmanun deneysel işlemleri öncesinde deney ve kontrol gruplarının öntest piyano eğitimi puanları arasında anlamlı bir fark olmadığı görülmektedir.

Tablo 5. Deney ve Kontrol Gruplarnndaki Öğrencilerin Öntest Armoni Eğitimi Puanlarının Karşılaştırılması

\begin{tabular}{lllllll}
\hline & & $\mathrm{N}$ & Mean Rank & Sum of Ranks & $\mathrm{Z}$ & $\mathrm{P}$ \\
\hline ÖnT armoni & 1,00 & 12 & 13,42 & 161,00 & $-0,6895$ & 0,551 \\
& 2,00 & 12 & 11,58 & 139,00 & & \\
& Total & 24 & & & & \\
\hline
\end{tabular}

Tablo 5'de deney ve kontrol gruplarındaki öğrencilerin öntest armoni eğitimi puanları üzerinde gerçekleştirilen analizsonuçları görülmektedir. Analizlere göre iki grubun armoni eğitimi testi puanları arasında $0,68 \mathrm{Z}$ değeri hesaplanmıştır. Bu sonuca göre araştırmanın deneysel işlemleri öncesinde deney ve kontrol gruplarının öntest armoni eğitimi puanları arasında anlamlı bir fark olmadığı görülmektedir.

Tablo 6. Deney ve Kontrol Gruplarındaki Öğrencilerin Öntest Müzik Biçimleri Testi Karşılaştırılması

\begin{tabular}{lllllll}
\hline ÖnT müzik Biçimleri & 1,00 & $\mathrm{~N}$ & Mean Rank & Sum of Ranks & $\mathrm{Z}$ & $\mathrm{P}$ \\
& 2,00 & 12 & 12,75 & 153,00 & $-0,1804$ & 0,887 \\
& Total & 24 & 12,25 & 147,00 & & \\
\hline
\end{tabular}


Tablo 6'de deney ve kontrol gruplarındaki öğrencilerin öntest müzik biçimleri testinden elde ettikleri puanlar üzerinde gerçekleştirilen analiz sonuçları görülmektedir. Analizlere göre iki grubun müzik biçimleri testi puanları arasında 0,18 $\mathrm{Z}$ değeri hesaplanmıştır. Bu bulguya göre araştırmanın deneysel işlemleri öncesinde deney ve kontrol gruplarının öntest müzik biçimleri testi puanları arasında anlamlı bir fark söz konusu değildir.

Tablo 7. Deney ve Kontrol Gruplarındaki Öğrencilerin Öntest Toplam Puanlarının Karşılaştırılması

\begin{tabular}{lllllll}
\hline & & $\mathrm{N}$ & Mean Rank & Sum of Ranks & $\mathrm{Z}$ & $\mathrm{P}$ \\
\hline ÖnToplam & 1,00 & 12 & 10,96 & 131,50 & $-1,0899$ & 0,291 \\
& 2,00 & 12 & 14,04 & 168,50 & & \\
& Total & 24 & & & & \\
\hline
\end{tabular}

Tablo 7'da deney ve kontrol gruplarındaki öğrencilerin öntest toplam puanları üzerinde gerçekleştirilen analiz sonuçları görülmektedir. İstatistiksel analizlere göre iki grubun öntest toplam puanları arasında 1,08Z değeri hesaplanmıştır. Bu bulguya göre araştırmanın deneysel işlemleri öncesinde deney ve kontrol gruplarının öntest toplam puanları arasında anlamlı bir fark söz konusu değildir. Araştırmanın öncesinde çalışma bağımlı değişkenleri açısından deney ve kontrol gruplarının birbirlerine denk olduğu söylenebilir. Deney ve kontrol gruplarının öntestteki genel durumu aşağıdaki grafikte gösterilmiştir.

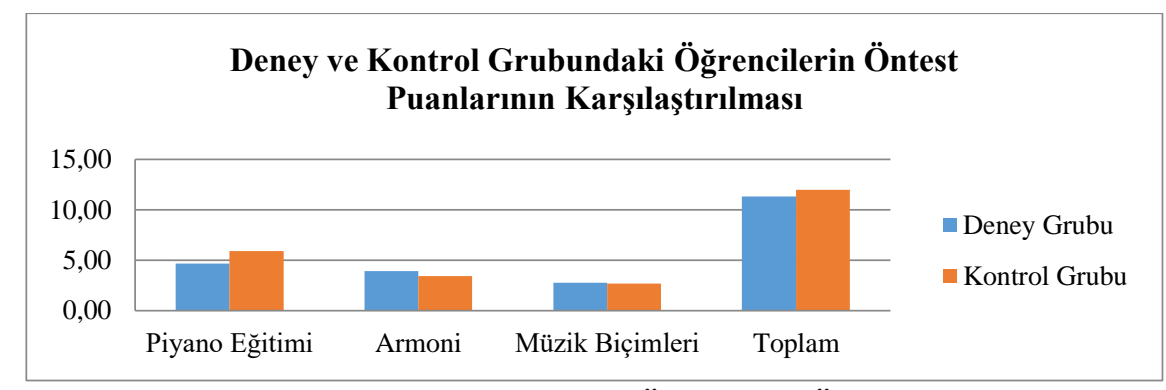

\section{Şekil 1. Deney ve Kontrol Grubundaki Öğrencilerin Öntest Puanlarının} Karşılaştırması

\section{Veri Toplama Araçları}

Araştırmada veri toplama aracı olarak 'Piyano Dersi Başarı Testi', ‘Öğrenme Stilleri Envanteri kullanılmıştır. 
Piyano dersi başarn testi: Uzman görüşlerine göre elde edilen 25 soruluk testin kapsam geçerliği açısından 3 boyuta sahip olduğu görülmüştür. Bu boyutlar, 'piyano eğitimi', 'armoni' ve 'müzik biçimleridir'. Başarı testin 1-13 sorular arasındaki 13 madde 'piyano', 14-20. Sorular arasındaki 7 madde 'armoni' ve 21-25 sorular arasındaki 5 madde ise 'müzik biçimleri' boyutuyla ilgilidir. Böylelikle deneme uygulaması için 3 ana boyutta, 25 maddelik bir başarı testi ortaya çıkmıştır. Ayrıca uzman görüşlerine dayalı olarak testle ilgili yapılan değerlendirmelerde testin süresi ve test maddelerinin öğrencilerin düzeyine uygun olup olmadığı, maddelerin zorluk düzeyleri ve uygun şekilde test içerisinde sıralanıp sıralanmadığı konularında ortak görüş birliği sağlanmaya çalışılmıştır. Bu şekilde piyano dersi başarı testinin kapsam geçerliği sağlanmıştır.

Öğrenme stilleri envanteri: Bu anket, bireylerin tercih ettikleri öğrenme stillerini saptamak için tasarlanmıştır. Ölçek Kolb (1984) tarafından geliştirilmiş ve Türkçe'ye adaptasyonu Aşkar ve Akkoyunlu (1993) tarafından gerçekleştirilmiştir. Kolb öğrenme stilleri envanteri zaman içinde bireye yardımcı olan ve öğrenme-öğretme süreçlerinde etkili olan alışkanlık ve tercihleri yansıtmaktadır.

Modelini uzun y1llar önce geliştiren David Kolb, 1984'te öğrenme stilleri modelini yayınladı. Bu model, Kolb'un deneyimsel öğrenme kuramı (ELT) ve Kolb'un öğrenme stilleri envanteri (LSI) gibi ürünlerin ortaya çıkmasını sağladı. Bir kişinin (ve sizin) öğrenme stilini bilmek, tercih edilen yönteme göre öğrenmenin yönlendirilmesini sağlar. Bununla birlikte, herkes, her tür öğrenme stilinin uyarısını bir dereceye kadar yantlar ve buna ihtiyaç duyar bu, verilen duruma ve bir kişinin öğrenme stili tercihlerine en iyi uyan vurgu kullanmaktır.

\section{Bulgular ve yorum}

Yapılandırmacı 5e+Öğrenme Stilleri modeline göre öğretim yapılan deney grubundaki öğrenciler ile geleneksel öğretim uygulanan kontrol grubundaki öğrencilerin arasında, sontest akademik başarı açısından anlamlı bir fark var midır? 
Tablo 8. Deney ve Kontrol Gruplarndaki Öğrencilerin Sontest Piyano Eğitimi Puanlarnnın Karşılaştırılması

\begin{tabular}{lllllll}
\hline grup & & N & Mean Rank & Sum of Ranks & Z & P \\
\hline SonTpiyano Egitimi & 1,00 & 12 & 17,08 & 205,00 & & \\
& 2,00 & 12 & 7,92 & 95,00 & $-3,239$ & 0,001 \\
& Total & 24 & & & & \\
\hline
\end{tabular}

Yapılandırmacı 5e modeli ve öğrenme stillerine dayalı uygulamaların yapıldığı deney grubu öğrencileri ile geleneksel öğretim uygulanan kontrol grubundaki öğrencilerin sontest piyano eğitimi puanları üzerinde gerçekleştirilen analiz sonuçları görülmektedir. Mann Whitney U testi ile gerçekleştirilen analizlere göre iki grup arasında 3,23 Z değeri hesaplanmıştır. Bu bulgu piyano eğitimi son test puanları açısından deney grubu lehine anlamlı bir fark olduğunu göstermektedir. Yapılandırmacı 5e modeli ve öğrenme stillerine dayalı etkinlikler öğrencilerin piyano eğitimi puanlarında anlamlı bir etkiyi ortaya çıkarmıştır.

Tablo 9. Deney ve Kontrol Gruplarndaki Öğrencilerin Sontest Armoni Ĕ̆itimi Puanlarnnin Karşılaştıriması

\begin{tabular}{lllllll}
\hline & & $\mathrm{N}$ & Mean Rank & Sum of Ranks & $\mathrm{Z}$ & $\mathrm{P}$ \\
\hline SonTarmoni & 1,00 & 12 & 15,71 & 188,50 & $-2,344$ & 0,024 \\
& 2,00 & 12 & 9,29 & 111,50 & & \\
& Total & 24 & & & & \\
\hline
\end{tabular}

Tabloda deneysel uygulamaların yapıldığ 1 deney grubu öğrencileri ile geleneksel öğretim uygulanan kontrol grubundaki öğrencilerin sontest armoni eğitimi puanları üzerinde gerçekleştirilen analiz sonuçları görülmektedir. Mann Whitney $U$ testi ile gerçekleştirilen analizlere göre iki grup arasında 2,34 Z değeri hesaplanmıştır. Bu bulgu armoni eğitimi son test puanları açısindan deney grubu lehine anlamlı bir fark olduğunu göstermektedir. Yap1landırmacı 5e modeli ve öğrenme stillerine dayalı etkinlikler öğrencilerin armoni eğitimi puanlarında anlamlı bir etkiyi ortaya çıkarmıştır.

Tablo 10. Deney ve Kontrol Gruplarndaki Öğrencilerin Sontest Müzik Biçimleri Testi Puanlarının Karşılaştırılması

\begin{tabular}{lllllll}
\hline & & N & Mean Rank & Sum of Ranks & Z & P \\
\hline SonTmüzik Biçimleri & 1,00 & 12 & 14,79 & 177,50 & $-1,6716$ & 0,114 \\
& 2,00 & 12 & 10,21 & 122,50 & & \\
& Total & 24 & & & & \\
\hline
\end{tabular}


Tabloda deney grubu öğrencileri ile kontrol grubundaki öğrencilerin sontest müzik biçimleri puanları üzerinde gerçekleştirilen sontest analiz sonuçları görülmektedir. Mann Whitney $U$ testi ile gerçekleştirilen analizlere göre iki grup arasında 1,67 Z değeri hesaplanmıştır. Bu bulguya göre müzik biçimleri sontest puanlarında deney ve kontrol grubu arasında manidar bir farklılık söz konusu değildir.

Tablo 11. Deney ve Kontrol Gruplarındaki Öğrencilerin Sontest Toplam Puanlarının Karşılaştırılması

\begin{tabular}{llllll}
\hline & & Mean Rank & Sum of Ranks & Z & P \\
\hline Deney Grubu & 12 & 17,79 & 213,50 & $-3,717$ & 0,000 \\
Kontrol Grubu & 12 & 7,21 & 86,50 & & \\
Total & 24 & & & & \\
\hline
\end{tabular}

Sontestte gruplar arasında hesaplanan son bulgu toplam puanlarla ilgilidir. Yapılandırmacı 5e modeli ve öğrenme stillerine dayalı uygulamaların yapıldığı deney grubu öğrencileri ile geleneksel öğretim uygulanan kontrol grubundaki öğrencilerin sontest toplam puanları arasında anlamlı bir fark bulunmuştur. $(Z=3,71 ; p<0,05)$. Bu son test toplam puanlar açısından deney grubu lehine anlamlı bir fark olduğunu göstermektedir. Uygulanan deneysel işlem kontrol grubuna kıyasla deney grubunda anlamlı bir etki oluşturmuştur. Sontestte deney ve kontrol gruplarının almış oldukları puan ortalamaları aşağıdaki grafikte gösterilmiştir.

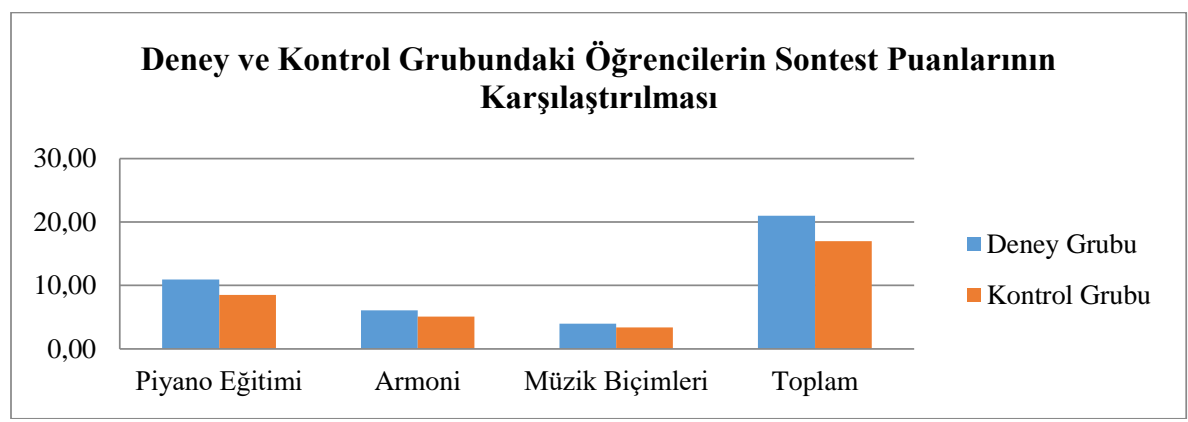

Şekil 2. Deney ve Kontrol Grubundaki Öğrencilerin Sontest Puanlarmm Karşılaştırılması

Yapılandırmacı 5E ve Öğrenme Stilleri modeline göre öğretim yapılan deney grubundaki öğrenciler ile geleneksel öğretim uygulanan kontrol grubundaki öğrencilerin, piyano dersi öğrenme kalıcılıkları arasında anlamlı fark var mıdır? 
Tablo 12. Deney ve Kontrol Gruplarnndaki Öğrencilerin Kalıcılık Testi Piyano Eğitimi Puanlarının Karşılaştırılması

\begin{tabular}{llllll}
\hline & $-n-$ & Mean Rank & Sum of Ranks & Z & p \\
\hline Deney Grubu & 12 & 15,92 & 191,00 & $-2,419$ &, 016 \\
Kontrol Grubu & 12 & 9,08 & 109,00 & & \\
\hline
\end{tabular}

Yapılandırmacı 5e modeli ve öğrenme stillerine dayalı uygulamaların yapıldığı deney grubu öğrencileri ile geleneksel öğretim uygulanan kontrol grubundaki öğrencilerin kalıcılık test piyano eğitimi puanları üzerinde gerçekleştirilen analiz sonuçları görülmektedir. Mann Whitney U testi ile gerçekleştirilen analizlere göre iki grup arasında 2,41 Z değeri hesaplanmıştır. Bu bulgu piyano eğitimi kalıcılık testi puanları açısından deney grubu lehine anlamlı bir fark olduğunu göstermektedir. Yapılandırmacı 5e modeli ve öğrenme stillerine dayalı etkinlikleröğrencilerin piyano eğitimi puanlarında anlamlı bir kalıcilığa yol açmıştır.

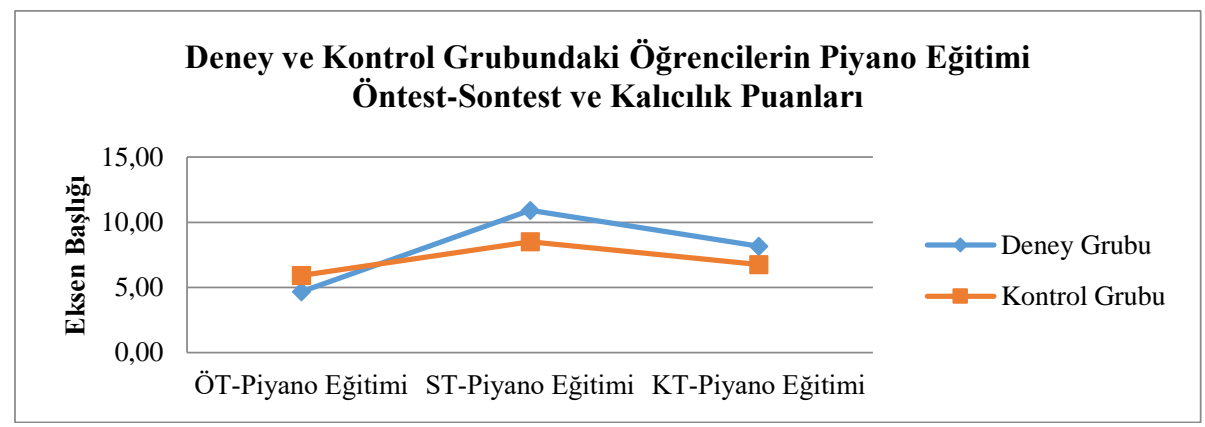

Şekil 3. Deney ve Kontrol Grubundaki Öğrencilerin Piyano Ĕ̆itimi Öntest-Sontest ve Kalıcilık Puanlar

Tablo 13. Deney ve Kontrol Gruplarındaki Öğrencilerin Kalıcılık Testi Armoni Eğitimi Puanlarının Karşılaştımlması

\begin{tabular}{llllll}
\hline & $\mathrm{N}$ & Mean Rank & Sum of Ranks & $\mathrm{Z}$ & $\mathrm{p}$ \\
\hline Deney Grubu & 12 & 14,63 & 175,50 & $-1,504$ &, 133 \\
Kontrol Grubu & 12 & 10,38 & 124,50 & & \\
\hline
\end{tabular}

Tabloda deneysel uygulamaların yapıldığı deney grubu öğrencileri ile geleneksel öğretim uygulanan kontrol grubundaki öğrencilerin kalıcılık armoni eğitimi puanları üzerinde gerçekleştirilen analiz sonuçları görülmektedir. Mann Whitney $U$ testi ile gerçekleştirilen analizlere göre iki grup arasında $1,504 \mathrm{Z}$ değeri hesaplanmıştır. Bu bulgu armoni eğitimi kalıcılık test puanları 
açısından anlamlı bir fark olmadığını göstermektedir. Armoni eğitimi puanlarında her iki grupta birbirlerine denk bir kalıcılık elde etmişlerdir.

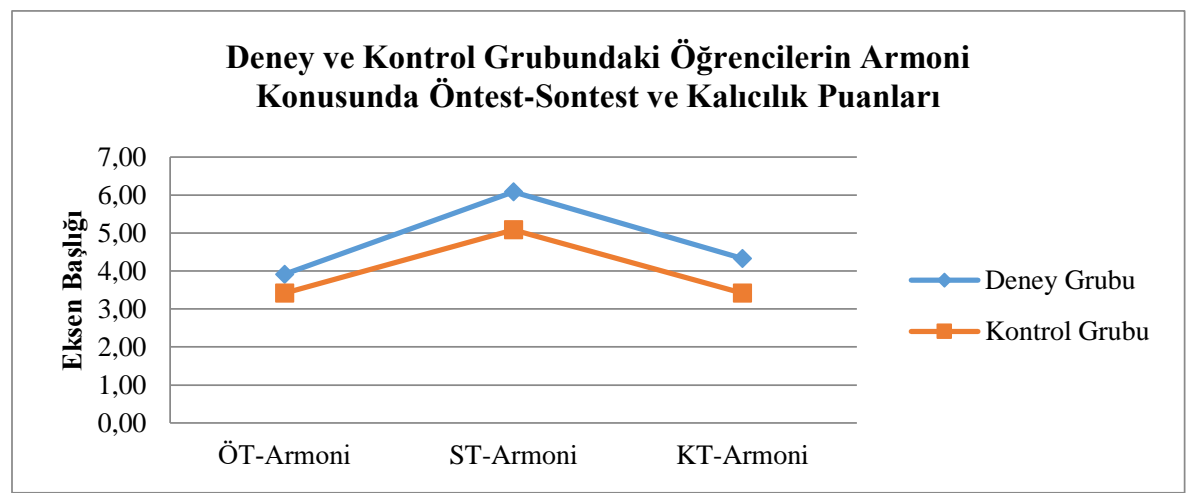

Şekil 4. Deney ve Kontrol Grubundaki Öğrencilerin Armoni Konusunda Öntest-Sontest ve Kalıclik Puanlarn

Tablo 14. Deney ve Kontrol Gruplarnın Kalıcılık Testi Müzik Biçimleri Konusundaki Puanlarının Karşılaştırılması

\begin{tabular}{lllllll}
\hline & & $\mathrm{N}$ & Mean Rank & Sum of Ranks & $\mathrm{Z}$ & $\mathrm{p}$ \\
\hline KalTmüzik & 1 & 12 & 14,13 & 169,50 & $-1,177$ &, 239 \\
Biçimleri & 2 & 12 & 10,88 & 130,50 & & \\
\hline
\end{tabular}

Tablo' da deney ve kontrol gruplarındaki öğrencilerin kalıcılık testi müzik biçimleri testinden elde ettikleri puanlar üzerinde gerçekleştirilen analiz sonuçları görülmektedir. Analizlere göre iki grubun müzik biçimleri kalıcılık testi puanları arasında 1,17 Z değeri hesaplanmıştır. Bu bulguya göre kalıclık testinde grupların puanları arasında anlamlı bir fark bulunamamıştır. Deney ve kontrol gruplarındaki öğrencilerin müzik biçimleri testinde birbirlerine denk bir kalıcılık düzeyi elde ettikleri söylenebilir. 


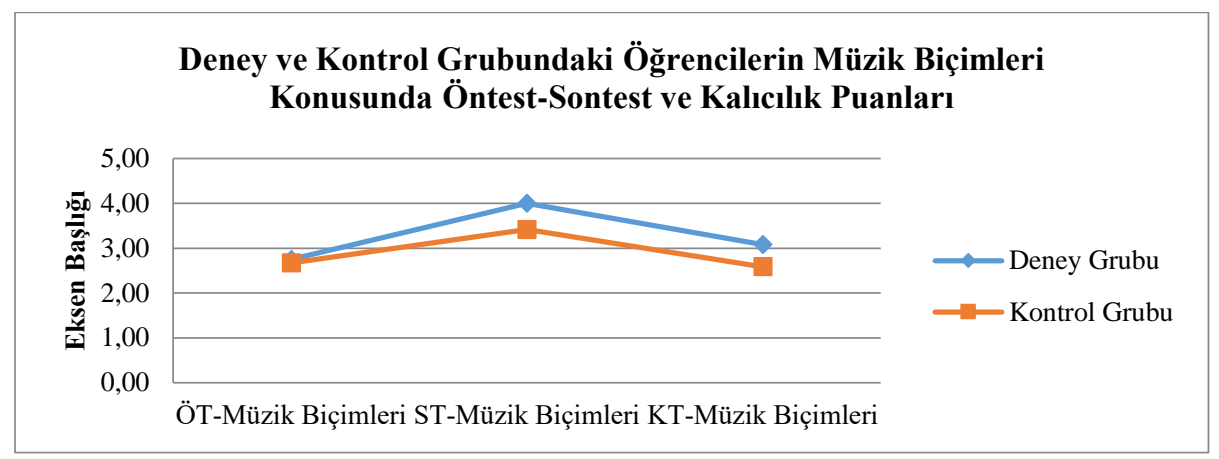

Şekil 5. Deney ve Kontrol Grubundaki Öğrencilerin Müzik Biçimleri Konusunda ÖntestSontest ve Kalıcilik Puanlar

Tablo 15. Deney ve Kontrol Gruplarının Toplam Kalıcılık Testi Puanlarının Karşılaştırilması

\begin{tabular}{|c|c|c|c|c|c|c|}
\hline & & $\mathrm{N}$ & Mean Rank & Sum of Ranks & Z & $\mathrm{p}$ \\
\hline \multirow[t]{2}{*}{ KalTtoplam } & 1 & 12 & 15,54 & 186,50 & $-2,124$ & ,034 \\
\hline & 2 & 12 & 9,46 & 113,50 & & \\
\hline
\end{tabular}

Kalıcilik testinde gruplar arasında hesaplanan son bulgu toplam puanlarla ilgilidir. Yapılandırmacı 5e modeli ve öğrenme stillerine dayalı uygulamaların yapıldığı deney grubu öğrencileri ile geleneksel öğretim uygulanan kontrol grubundaki öğrencilerin kalıclık testi toplam puanları arasında anlamlı bir fark bulunmuştur. $(Z=2,14 ; p<0,05)$. Kalıcılık testi toplam puanlar açısından deney grubu lehine anlamlı bir fark söz konusudur. Uygulanan deneysel işlem kontrol grubuna kıyasla deney grubunda anlamlı bir kalıcılık düzeyi oluşturmuştur. Kalıcılık testinde deney ve kontrol gruplarının almış oldukları puan ortalamaları aşağıdaki grafikte gösterilmiştir.

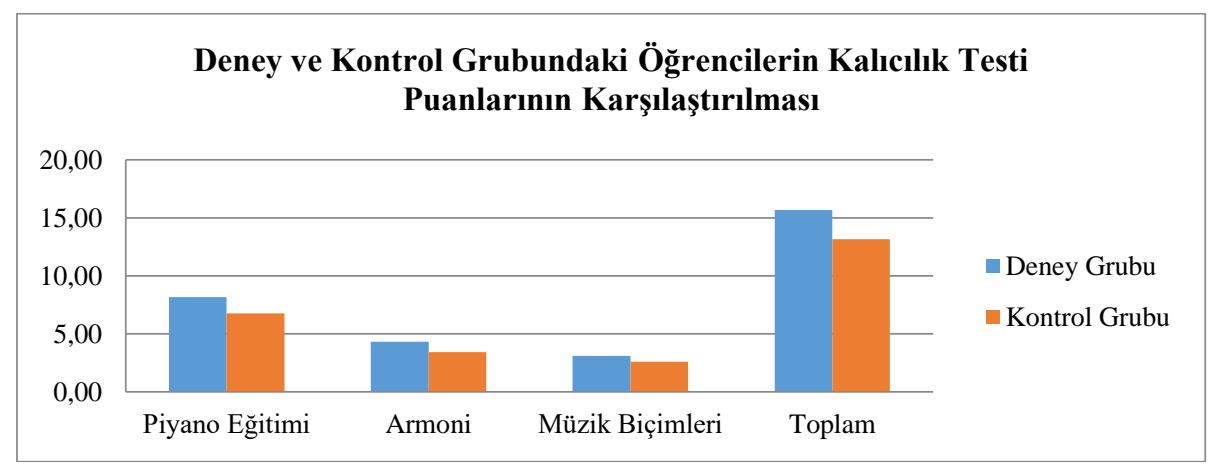

Şekil 6. Deney ve Kontrol Grubundaki Öğrencilerin Kalıcılk Testi Puanlarmun Karşılaştırılması 


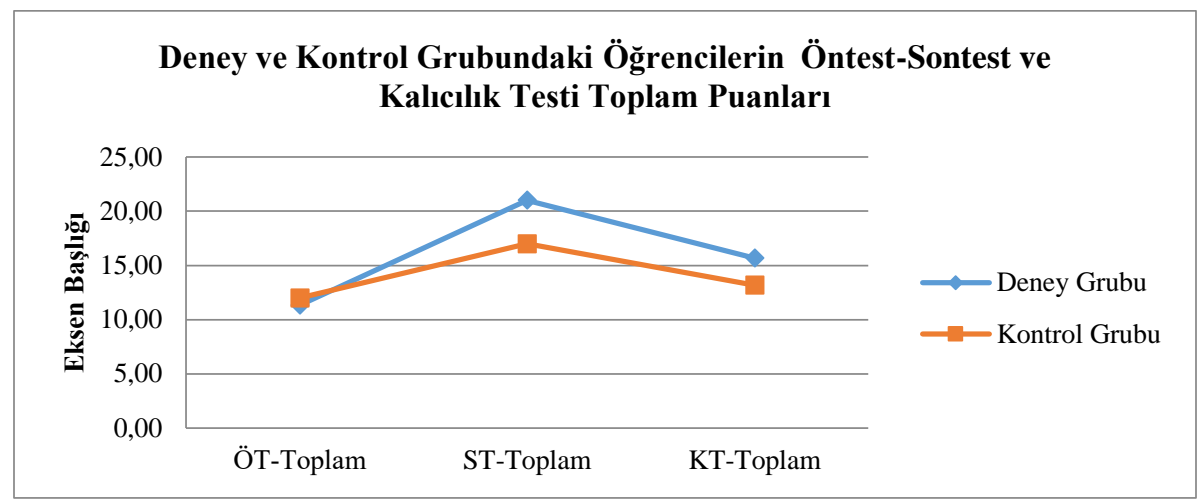

Şekil 7. Deney ve Kontrol Grubundaki Öğrencilerin Öntest-Sontest ve Kalıcılık Testi Toplam Puanlan

\section{Sonuç, tartışma ve öneriler}

Piyano eğitiminde 5E modeli ve öğrenme stillerine dayalı etkinliklerin uyguladığı bu karma modelli araştırmanın nicel ve nitel boyutlarında aşağıdaki sonuçlara ulaşılmıştır.

Yapılandırmacı 5e modeli ve öğrenme stillerine göre öğretim yapılan deney grubu ile geleneksel öğretim metodu uygulanan kontrol grubunun piyano dersi sontest puanları arasında anlamlı bir fark vardır. Deney grubundaki öğrenciler anlamlı düzeyde yüksek piyano dersi başarısı, uygulanan deney grubu öğrencileri geleneksel öğretim uygulaması yapan arkadaşlarına kıyasla yüksek düzeyde öğrenme kalıcılığı elde etmişlerdir.

Araştırmada 5E Modeli ve öğrenme stillerine dayalı öğretimin birlikte uygulandığı deneme grubundaki öğrencilerin geleneksel öğretim yapılan kontrol grubundaki arkadaşlarından anlamlı düzeyde yüksek piyano dersi başarısı elde ettikleri görülmüştür. Bu bulgular Gök (2011) ve Uzunluoğlu Yegül'ün (2013) müzik eğitiminde yapılandırmacı öğrenmenin etkilerini test ettikleri araştırmaların sonuçları ile benzerlik göstermektedir.

$5 \mathrm{E}$ modeli ve öğrenme stillerine dayalı öğretim etkinliklerini bir arada uygulayan öğrenciler sistematik bir yaklaşımla kendi öğrenme süreçlerine göre etkinlikleri aktif olarak yapılandırmışlar, aşamalı bir şekilde görsel, işitsel ve kinestetik aktiviteler gerçekleştirmişler ve kubaşık stratejinin deneysel işleminde kendi öğrenme süreçlerini sorgulamışlardır. Bu bütüncül yaklaşım 5E 
modeli ve öğrenme stillerine dayalı öğretimin uygulamasının piyano dersi başarısı üzerinde yüksek etki oluşturmasına yol açmıştır.

Nolen ve Thomas'a göre (1990) belirli bir tutarlılık içerisinde bir çok öğretim yöntemi bir arada işlendiği zaman öğrenci performansını artırmaktadır. Derste etkinlikler içinde ve arasındaki farklılıkları vurgulayan öğrenme stilleri ve zengin öğrenme yaşantılarını ön plana çıaran yapılandırmacı öğrenme yaklaşımı yüksek piyano dersinde yüksek kalıclık ve öğrenme düzeyi sağlamiştır.

Araştırmanın bulguları bir bütün olarak değerlendirildiğinde yapılandırmacı ve öğrenme stillerine dayalı piyano eğitiminde her bir öğrencinin tercih, ilgi, ihtiyaç, öğrenme yaşantıları ve bireysel farklılıkları dikkate alınarak, öğretim yöntemleri, öğrenme ortamı, ölçme-değerlendirme teknikleri düzenlenmiştir. Bu anlayış çerçevesinde piyano dersinin düzenlenen öğrenme ortamlarında, öğrenciler aktif bir şekilde öğrenme sürecinde sorumluluk almışlar, kendi öğrenme stillerini uygulayarak dersin kazanımlarını elde etmeye çalışmışlardır. Tüm bunlar piyano dersinde yüksek başarıyı, kalıcılığı ve olumlu yönde duyuşsal öğrenme ürünlerini ortaya çıkarmıştır.

Piyano eğitiminde 5E modeli ve öğrenme stillerine dayalı etkinliklerin uyguladığı bu tezin sonuçlarına dayalı olarak aşağıdaki öneriler ileri sürülebilir:

Piyano eğitiminde gerçekleştirilen $5 \mathrm{E}$ modeli ve öğrenme stillerine dayalı etkinlikler farklı müzik derslerinde de uygulanabilir.

$5 \mathrm{E}$ modeli ve öğrenme stillerine dayalı etkinlikler farklı öğretim kademelerinde müzik dersi öğretim programlarına yerleştirilebilir.

Piyano eğitiminde, armoni ve müzik biçimleri derslerinin konuların içeren farklı etkinlikler hazırlanıp, öğrencilerin piyanoya karşı bilişsel, duyuşsal ve devinişsel becerilerinde kalıcılı̆̆ı artıracak uygulamalar hazırlanabilir. 


\title{
EXTENDED ABSTRACT
}

\section{Effects Of Learning Styles And 5E Model Activities On Success And Permanently In Piano Education}

\author{
Yavuz Selim Kaleli - Aynur Elhan Nayir \\ Necmettin Erbakan University
}

During piano education, it becomes more efficient to notice individual differences and to practice in teaching. This is due to the one-to-one implementation of the training. It is important for the educator to get to know the student and to be prepared according to the order of individual learning. The educator can teach the learner styles efficiently and effectively in $p$ dersiyanoi.

Piano education is an important value in the individual's cognitive, affective and psychomotor learning experiences. Piano educators are expected to perform activities according to their higher education styles and to take a more active role in higher education. In piano education, if my curriculum is low, the educational programs should take the question of students' learning styles.

The purpose of this study is that the study of the piano area has learned to learn the constructivist and learning styles to be given, instead of playing the piano without paying attention to the harmony, form and technical characteristics of the piece. The practice of "Piano Education Based on Model and Learning Styles" and to reveal a response to this individual's piano playing skill and permanence.

Research test Piano lesson achievement test, piano playing skill observation form and attitude scales for piano lesson were applied to both groups as a pretest before the experimental process. Following the pretest application, a 10-week experimental procedure was performed for the interim experimental and control groups. The same tests and scales were applied to the experimental and control groups as a posttest. At this stage, the traditional teaching practice was carried out in the control group for the experimental training to the constructivist learning 5E model + Learning Styles application. 3 months after the posttest application, the piano lesson success test was applied as a "retention test" to all groups. 
In the experimental part of the study, a pre-evaluation form including general technical and musical expressions in piano education was prepared for the experiment in case of a significant difference between experimental control and experiment. The experiment was implemented, which was learned to be suitable for the Learning Style of Kolb experienced experimentally, and a 10-week piano training application was planned and carried out according to the 5E Model + learning program.

In this practice, activities that include Harmony, Music Forms lesson, and Piano lessons, which are also given as other lessons today, and that will guide the individual in structuring his gains, took place. The determination of the harmony functions in which the individual will use the cognitive field skill in the piano piece, the determination of the piano piece form and the musical period difference, the solfege in the tone of the piece to be played, where the affective field skill will be used (e.g., when playing the left hand, applying the solfege of the right hand or solfege of the right hand, etc.), kinesthetic The elements that will guide the individual in structuring these separate lessons have been replaced by deriving both the weighing and the sounds of the piece with technical difficulties to use the field skill and writing it to increase the piano lesson.

Test the experimental and control groups in the size of the experiment model of the constructivist 5e model in piano education and the applications of the learner styles to the individual's piano lesson success, piano playing skill, attitudes towards the lesson and the retention of the learned. 24 students who took piano education at Necmettin Erbakan University, Ahmet Keleşoğlu Faculty of Education, Department of Music Teaching in the 2016-2017 academic year were included in the study. These students were randomly assigned to two groups of 12 each. Then, by chance, these groups are grouped as experimental and control groups. In this process, attention has been paid to assigning equal groups in terms of lessons.

Piano lesson achievement test, 25-question test, which was obtained according to expert opinions, was observed to have 3 dimensions out of scope. These dimensions are "piano education", "harmony" and "musical forms". The 13 items between 1-13 questions of the achievement test are 'piano', 1420.7 items between questions are "harmony" and 5 items between 21-25 questions are with "musical styles" dimension. Thus, an achievement test of 25 items in 3 main dimensions emerged for the trial application. The test is in 
accordance with the test duration and testing time and the high level of the test, the questioning is tested with the test in accordance with the expert opinions in order to ask the test with the high test result.

\section{Kaynakça / References}

Aşkar, P. ve Akkoyunlu, B. (1993). Kolb öğrenme sitili envanteri. Eğitim ve Bilim, 87, 37-47.

Bayar, F. (2005). İlköğretim 5. smuffen bilgisi öğretim programmnda yer alan $1 s ı$ ve ısının maddedeki yolculuğu ünitesi ile ilgili yaplandirmac yaklaşıma uygun etkinliklerin geliştirilmesi. Yüksek Lisans Tezi, KTÜ Fen Bilimleri Enstitüsü, Trabzon.

Ekici, G. (2002). Gregorc öğrenme stili ölçeği. Eğitim ve Bilim Dergisi, 123, 42-47.

Gök, M.. (2012). Müzik eğitiminde 5e modelinin akademik başarı, tutum ve kalıchlı̆̆a etkisi. Yayınlanmamış Doktora Tezi, Gazi Üniversitesi, Eğitim Bilimleri Enstitüsü Karasar, N. (2005). Bilimsel araştırma yöntemi (14. Baskı). Ankara: Nobel Yayın Dağıtım.

Nolen, Susan B. ve Thomas M. Haladyna. (1990).Personal and environmental infuences on students' beliefs about effective study strategies. Contemporary Educational Psychology, 15, 116-130.

Uzunoğlu Yegül, Belgin (2013). Yapılandırmacı yaklaşım temelli müziköğretiminin öğretmen adaylarmin ders öğretme-öğrenme süreçlerine etkisi. Yayınlanmamış Doktora Tezi, Marmara Üniversitesi, Eğitim Bilimleri Enstitüsü.

\section{Kaynakça Bilgisi / Citation Information}

Kaleli, Y. S. ve Nayır, E. N. (2020). Piyano eğitiminde öğrenme stilleri ve 5e modeline yönelik etkinliklerin başarı ve kalıcılığa etkisi OPUSUluslararası Toplum Araştırmaları Dergisi, 16(30), 2595-2615. DOI: 10.26466/opus.728457 